\title{
TIETOJA VUOSIKIRJASTA
}

Kulttuuripolitiikan tutkimuksen vuosikirja on tieteellinen julkaisu, joka tuo yhteen useilla eri tieteenaloilla tehtävää kulttuuripolitiikkaa koskevaa tutkimusta. Julkaisu ilmestyy Internetissä ja on vapaasti kaikkien saatavilla.

Vuosikirjaa julkaisee Kulttuuripolitiikan tutkimuksen seura ry. Seuran tarkoitus on koota yhteen monitieteistä ja monipuolisille tulkinnoille avointa kulttuuripolitiikan tutkimusta. Se edistää tutkijoiden, hallinnon ja erilaisten kulttuuripolitiikan toimijoiden yhteistyötä Suomessa ja kansainvälisesti sekä edesauttaa tutkimustulosten soveltamista käytäntöön. Lisätietoja seurasta löydät yhdistyksen kotisivuilta osoitteesta www.kulttuuripolitiikantutkimus.fi.

Vuosikirjassa julkaistaan vertaisarvioituja tieteellisiä artikkeleita, suppeampia tieteellisiä avauksia (research notes) ${ }^{1}$ sekä tutkimuksenalaan liittyviä kolumneja. Lisäksi julkaisu voi sisältää katsauksia ja kirja-arvioita, lektioita sekä alaa koskevista väitöskirjoista annettuja vastaväittäjän lausuntoja.

Kaikki vuosikirjassa julkaistut artikkelit ovat käyneet läpi Tieteellisten Seurain Valtuuskunnan hyväksymän vertaisarviointimenettelyn. Toimituksen luettua ja hyväksyttyä saapuneen artikkelin se siirtyy kahdelle anonyymille vertaisarvioijalle, jotka laativat arvionsa kahden kuukauden kuluessa. Sen jälkeen tekstit palautetaan tekijöiden korjattaviksi ja uudelleen vuosikirjaan lähetettäviksi.

Kulttuuripolitiikan tutkimuksen vuosikirjan pääkieli on suomi, mutta sen julkaisukieliä ovat myös ruotsi ja englanti. Kaikista referee-artikkeleista julkaistaan englanninkielinen tiivistelmä.

Kulttuuripolitiikan tutkimuksen vuosikirjan toimituskunta ottaa mielellään vastaan erityyppisiä tekstejä julkaistavakseen. Tarkempia ohjeita vuosikirjassa julkaisemista varten löydät vuosikirjan sivuilta OJS-alustalla, journal.fi/kultpol.

1. Tieteellinen avaus (research notes) tarkoittaa sisällöltään tieteellistä tekstiä, joka ei kuitenkaan ole täyspitkä tieteellinen artikkeli. Tekstin tavoitteena on esitellä uutta tutkimusideaa, teoreettista näkökulmaa tai menetelmällistä lähestymistapaa. Tieteellinen avaus tarjoaa mahdollisuuden tieteellisen ajattelun kehittämiselle ja tutkimukselliselle ideoinnille. Siksi myös kirjoitus voi olla muodoltaan hieman vapaampi kuin artikkeli. 